OPEN ACCESS

Edited by: Sanjiv Dhingra,

University of Manitoba, Canada

Reviewed by:

Danish Sayed

Rutgers Biomedical and Health

Sciences, United States

Niketa Sareen,

Sant'Anna School of Advanced

Studies, Italy

*Correspondence:

Acelya Yilmazer

ayilmazer@ankara.edu.tr

Specialty section:

This article was submitted to

Cardiovascular Biologics and

Regenerative Medicine,

a section of the journal

Frontiers in Cardiovascular Medicine

Received: 26 October 2021

Accepted: 13 January 2022

Published: 11 February 2022

Citation:

Gokce C, Gurcan C, Delogu LG and Yilmazer A (2022) 2D Materials for

Cardiac Tissue Repair and

Regeneration

Front. Cardiovasc. Med. 9:802551.

doi: 10.3389/fcvm.2022.802551

\section{D Materials for Cardiac Tissue Repair and Regeneration}

\author{
Cemile Gokce ${ }^{1}$, Cansu Gurcan 1,2, Lucia Gemma Delogu ${ }^{3}$ and Acelya Yilmazer 1,2* \\ ${ }^{1}$ Department of Biomedical Engineering, Ankara University, Ankara, Turkey, ${ }^{2}$ Stem Cell Institute, Ankara University, Ankara, \\ Turkey, ${ }^{3}$ Department of Biomedical Sciences, University of Padua, Padua, Italy
}

Cardiovascular diseases (CVDs) have a massive impact on human health. Due to the limited regeneration capacity of adult heart tissue, CVDs are the leading cause of death and disability worldwide. Even though there are surgical and pharmacological treatments for CVDs, regenerative strategies are the most promising approaches and have the potential to benefit millions of people. As in any other tissue engineering approach, the repair and regeneration of damaged cardiac tissues generally involve scaffolds made up of biodegradable and biocompatible materials, cellular components such as stem cells, and growth factors. This review provides an overview of biomaterial-based tissue engineering approaches for CVDs with a specific focus on the potential of 2D materials. It is essential to consider both physicochemical and immunomodulatory properties for evaluating the applicability of 2D materials in cardiac tissue repair and regeneration. As new members of the 2D materials will be explored, they will quickly become part of cardiac tissue engineering technologies.

\footnotetext{
Keywords: two-dimensional nanomaterials, conductive biomaterials, cardiovascular disease, stem cell therapy, cardiovascular regeneration
}

\section{INTRODUCTION}

The field of biomaterials involves different scaled materials from macro-size to micro- and nanosized materials categorized into polymers, ceramics, metals, and composites. Biomaterials work in conjunction with the living matter, directly replacing or restoring the damaged parts of the body that are tissues or organs by performing intended body functions and thus improving the quality of human life. They can exist naturally or be synthesized with specific functionality. Over the past few decades, they have been used in a variety of biomedical applications such as dental and orthopedic implants, sutures, joint replacements, heart valves, vascular grafts, contact lenses, pacemakers, burn dressing as well as drug delivery systems, and biosensors $(1,2)$. These applications rely on significant parameters such as biocompatibility, non-toxicity, host response (bioresorbable, bioinert, or bioactive), corrosion, wear, fatigue, design, and manufacturability. For example, polymers comprise the largest class of biomaterials and can be both natural and synthetic. They are covalently-bonded and mostly nonconducting materials used in drug delivery and soft and hard tissue applications. On the other hand, ceramics like calcium phosphates $(\mathrm{CaP})$ and alumina $\left(\mathrm{Al}_{2} \mathrm{O}_{3}\right)$ are characterized via ionic bonds, excellent biocompatibility, high corrosion resistance, wear, strength, hardness, and stiffness. However, metals such as stainless steel and titanium have great strength, resistance to fracture toughness, better elasticity, and rigidity compared to polymers and ceramics. They are mostly used in dental and orthopedics applications (3). 
2D materials (2DMs) refer to materials that are composed of thin layers with a thickness of a single or few atomic layers (4). The known 2DMs in literature are graphene (Gr), graphene derivatives (GDs) like graphene oxide (GO) and reduced GO (rGO), black phosphorus (BP), transition metal dichalcogenides (TMDs) such as molybdenum disulfide $\left(\mathrm{MoS}_{2}\right)$, and tungsten disulfide $\left(\mathrm{WS}_{2}\right)$, layered double hydroxides (LDHs), hexagonal boron nitride (h-BN), and transition metal carbides (MXenes). They possess unique intrinsic physicochemical properties such as high surface to volume ratio, excellent mechanical properties, electrical conductivity, and surface functionality which can be suitable for use in tissue engineering applications such as repair and regeneration of damaged cardiovascular tissues (CVTs) $(5,6)$. The damage in the CVTs can be caused by fat accumulation, platelet aggregation, and formation of blood clots resulting in CVDs such as ischemic stroke and myocardial infarction (MI) (7). Adult human heart has very low regenerative capacity, therefore, any cardiac damage in middle-aged or older people results in heart failure $(8,9)$. CVDs are major health problems in the United States of America, affecting 85.6 million American lives. According to WHO, CVDs account for 17.9 million deaths in 2019, 32\% of all global deaths $(10,11)$. For this reason, novel approaches are required to reverse the CVD progression. Thanks to their intrinsic properties, 2DMs are promising candidates which can overcome the limitations or improve the performance of conventional biomaterials or other available therapies (Figure 1). Scaffolds containing 2D materials can allow effective proliferation and differentiation of stem cells, and contribute toward the regeneration of damaged cardiac tissue through its angiogenic, immunomodulatory, and electrical properties. This review article introduces the current clinical therapeutic approaches for CVDs, and their limitations are discussed. Later, biomaterial and nanomaterial-based studies are explored with a specific focus on 2DMs to delineate their potential in the regeneration and repair of CVTs.

There are several adult stem cells such as hematopoietic stem cells (HSCs), mesenchymal stem cells (MSCs), cardiac stem cells (CSCs), and endothelial progenitor cells (EPCs) which are used in clinical applications of cardiovascular therapies (12). Among them, the treatment of CVDs with mesenchymal stem cells (MSCs) is a good candidate and is used commonly for tissue regeneration due to the immunomodulatory and vascular repair capabilities of MSCs. They are multipotent progenitor cells with self-renewing properties and are found in different tissues like adipose tissue, bone marrow, and umbilical cord blood as cell sources $(13,14)$. According to their sources, MSCs can exhibit different properties, including immunomodulatory and paracrine effects, and differentiation into specific cell types (15). For CVD, they have already reached pivotal phase III trials after successful completion of phase I and II clinical trials $(7,16)$. Prior to clinical trials, large animal models like pigs, dogs, and sheep are better at testing the feasibility, efficacy, and long-term safety of therapeutic approaches for cardiac regeneration due to their similarity to human physiology and anatomy. These models select an optimal number of transplanted cells and the time of transplantation to deliver and track transplanted MSC. Nevertheless, these models have a high maintenance cost and long-life cycle, unlike small animal models like rodents $(17,18)$. Even though MSCs are found not to initiate immunological reactions within 12 months post-transplantation in many clinical trials, they promote anti-inflammatory actions (19-21). Bone marrow-MSCs are commonly used in clinical trials of acute/subacute MI and found to be safe for a small group of patients who had acute MI at short and long-term follow-up (22). Trials with adipose tissue-MSCs have been performed to test their efficacy in myocardial regeneration. It has been shown that adipose tissue-MSCs enhance cardiac function and decrease scar tissue (23). Additionally, umbilical cord Wharton's jelly (WJ)-derived MSCs express higher proliferative potential, safe, beneficial, and feasible in trials for treating acute MI $(15,24,25)$. In another trial with autologous MSCs, therapeutic effects such as decrease in scar tissue, increase in heart mass, and contractility have been successfully observed $(26,27)$. Later, allogeneic and autologous bone marrow-MSCs are compared for the treatment of chronic ischemic cardiomyopathy (CIC). Both allogenic and autologous cells show similar results, including a decrease in scar size and enhancement of ejection fraction (28). Bone marrow-MSCs cause a decrease in infarct size and improvements in contractility, although no change in ejection fraction was observed (29). Likewise, administration of autologous MSCs into patients undergoing cardiac surgery results in decreased scar size, improvements in contraction, and tissue perfusion (30). Stem cell-based therapies based on bone marrow-derived MSCs can also improve heart regeneration via transplanting non-cardiac cells because there are not enough functional cardiomyocytes to replace the lost myocardium $(28,31,32)$. Adipose tissue-MSCs are also tested for treating seriously ill CIC patients and show improvements in heart contraction, perfusion, and left ventricle mass (33). In a slightly different approach, MSCs are stimulated with cardiogenic cytokines before transplantation in order to improve therapeutic efficacy (34). A similar strategy is performed by stimulating adipose tissue-MSCs with vascular endothelial growth factor (VEGF) (35). In conclusion, MSCs generally improve the quality of life by decreasing the size of scar tissue, increasing contractility and tissue perfusion of the injured heart, inducing the formation of new blood vessels, and antifibrotic effects at the damaged cardiac tissue. However, these therapies have major limitations, including poor in vivo survival rate after transplantation, and insufficient adult stem cell delivered to the damaged target area $(7,36,37)$. The small number of participants and the lack of a placebo group in clinical trials may also restrict the therapy's positive generalized effect, such as long-term safety. These limitations may be overcome by priming MSCs with stem cell modulators used for intracellular signal triggering prior to transplantation or via alternative strategies such as scaffolds involving natural polymers or nanomaterials $(9,38)$.

\section{BIOMATERIALS IN CARDIOVASCULAR REGENERATION}

Current cardiac therapies face challenges such as the minimal intrinsic regenerative capacity of heart tissue, poor integration, and implanted cell survival (39). Thus, there is an urgent need 

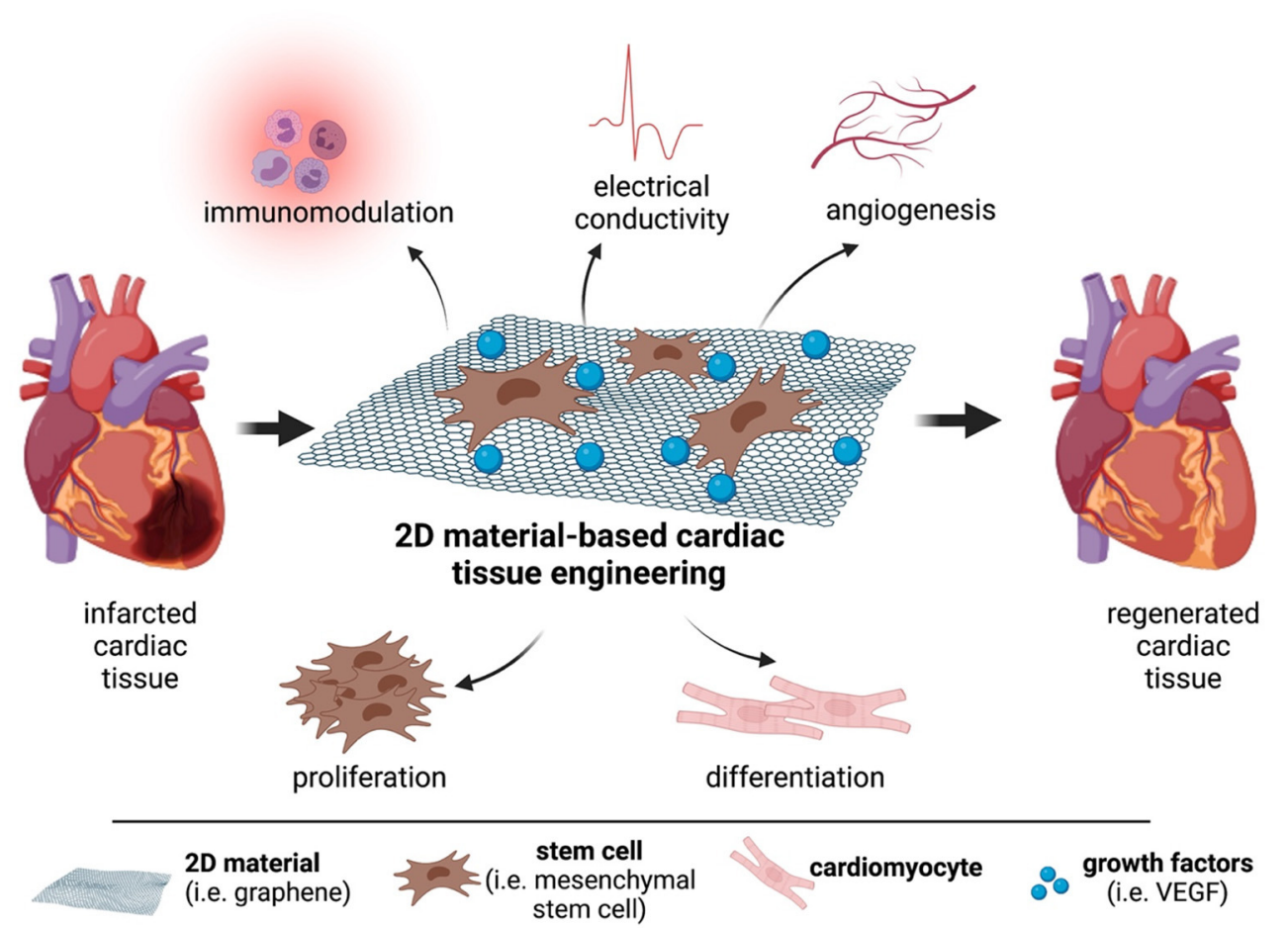

FIGURE 1 | The potential of 2D materials for cardiac repair and regeneration. Graphene or graphene derivatives can act as scaffolds for mesenchymal stem cells and deliver growth factors to the infarcted area. This strategy can allow the regeneration of the damaged cardiac tissue.

for cheaper and less invasive cardiac treatment approaches via biomaterials or nanomaterials. The biomaterials-based approach is one of the most plausible ways to attain clinically successful cardiac therapies. Biomaterials used in cardiac repair should be biocompatible, biodegradable, enable cell integration with native tissue, decrease hostility of the local microenvironment and control the slow release of bioactive molecules (40-42). Both synthetic biomaterials like polylactic-co-glycolic acid (PLGA), polyurethane, and carbon nanotubes (CNTs) and natural biomaterials like fibrin, gelatin, alginate, collagen, and chitosan can be used alone as a carrier or serve as an artificial extracellular matrix (ECM) scaffold to repair and regenerate CVTs (42-44). The myocytes and other cells in the heart interact with the ECM, which comprises inotropic stimuli and growth signals for cell recruitment and maturation (45). Other cells in the heart are stem cells like mononuclear cells (MNCs), embryonic stem cells (ESCs), bone marrow-MSCs, and/or progenitors like EPCs, and transplantation of these cells mainly provides the formation of new and functional myocardial tissue. These cells can be mixed with biomaterials for direct delivery to the target area or cultured on biomaterials $(46,47)$. This mixing or culturing indicates better transplantation, survival, differentiation, and functioning of the cells in the heart and thus further development in cardiac tissue regeneration. Besides, the materials for cell delivery should have an optimal degradation time for the electromechanical integration of transplanted cells $(48,49)$. Growth factors such as transforming growth factor- $\beta$ (TGF- $\beta$ ) and bone morphogenetic protein 4 (BMP4) play an essential role in mediating cardiac tissue regeneration. Based on this knowledge, the therapeutic potential of injectable biomaterials like hydrogels against MI and peripheral artery disease (PAD) has been investigated in animal models (50). In vivo injection of keratin biomaterials and platelet gels can provide sustained release of growth factors which preserved cardiac tissue, promoted angiogenesis, and decreased left ventricular wall dilatation. Their porous structure also allows the endothelial cells, cardiomyocytes, and other progenitor cells to grow on the scaffold, making them good candidates for cardiac repair $(44,51)$. Solid forms of alginate, a naturally occurring polysaccharide found in algae, like hydrogels and microporous scaffolds, are used for biomaterialassisted stem cell transplantation for the failing cardiac tissue (52). This transplantation replaces lost stem cells in the heart and encourages native cardiac tissue regeneration. Concerning this, Levit et al. have designed a hydrogel delivery platform for stem cell transplantation. They have encapsulated human MSCs (hMSCs) in an alginate hydrogel. After encapsulation, MSCs have been attached to the damaged rat heart with a PEG hydrogel patch for stem cell protection. The study results have concluded that alginate encapsulation enhances retention of hMSCs and facilitates paracrine effects such as increased microvascular density and reduced scar size, providing cellmediated cardiac repair (53). Roche et al. have carried out a study to evaluate whether acute retention can be improved with biomaterial carriers. They have used a thermosensitive 
chitosan $/ \beta$-glycerophosphate gel, alginate, and collagen patches as the hMSC vehicles, chitosan hydrogel as a delivery vehicle for adipose tissue-MSCs in myocardial repair. They have displayed promising results that all studied biomaterials have influenced the part where cells are localized and improved retention of cells in the myocardium (54). Biomaterials, especially polymers including fibrin, alginate, collagen, poly(L-lactic acid) (PLLA), and poly(glycerol sebacate) (PGS) with inherent characteristics have also been used to control the differentiation process of induced pluripotent stem cells (iPSCs) as well as increasing the quality and efficiency of their traditional expansion to get an advanced iPSC research. They do this by creating the native microenvironment of stem cells, namely stem cell niche $(55,56)$.

In addition to biomaterials, nanomaterials in the forms of nanostructured surfaces, nanoparticles, and nanocomposites have unprecedented potential to enhance the therapeutic performance of conventional biomaterials. These nanomaterials can be gold nanoparticles (Au NPs), silver (Ag) NPs, polymeric NPs, cerium oxide $\left(\mathrm{CeO}_{2}\right)$ NPs (nanoceria). Their size ranges from protein level to cellular level and can mimic the native ECM components of tissues and the cardiac microenvironment (5759). They have physiochemical properties such as high surfaceto-volume ratio, surface roughness, hydrophilicity, high surface energy, and reactivity, promoting better protein adhesion and direct cell activities. This ability to direct cell fate selectively is useful in specific cardiovascular studies where it is preferable to stimulate the functions of some cell types while suppressing the activities of another cell type (60-62). They cause oxidative stress by producing ROS, which is one of the main players of inflammation. Moreover, integrating nanoscale components of different sizes, morphology, function, and chemical composition into a matrix material is also a more reliable approach to obtain complementary properties required for effective therapy. Briefly, they can either induce immune suppression or stimulation depending on their size, surface chemistry, composition, protein binding, and exposure route $(59,63)$. Immunosuppression occurs when the functioning of the immune system disrupts and thus causes non-effective clearance of pathogens, whereas immunostimulation enhances the response of the immune system specifically to resist pathogens (64). For instance, Nanoceria has been found to uptake by the cardiac progenitor cells (CPCs), reduce ROS as an antioxidant agent, and protect the cardiac progenitor cells from $\mathrm{H}_{2} \mathrm{O}_{2}$-induced cytotoxicity (65). It has also suppressed the activity of the innate immune system in Paracentrotus lividus ( $P$. lividus), Mediterranean species of the sea urchin (66). Mukherjee et al. have developed a PLLA/poly( $\varepsilon$-caprolactone)/collagen nanostructured matrix mimicking the native myocardium microenvironment. This hydrophilic nanofibrous biocomposite scaffold has been used to culture and support isolated rabbit cardiomyocytes. They have demonstrated superior attachment and growth of adult rabbit cardiomyocytes (67). Chang et al. have conjugated insulin-like growth factor (IGF)-1 to PLGA nanoparticles and delivered to the damaged area after acute MI. In this study, the complex has increased IGF-1 retention, improved left ventricle function, and provided early cardioprotection (68). Martins et al. have described electrically conductive CNTs/chitosan scaffolds as having similar mechanical properties to native cardiac muscle. The scaffold has supported the survival of neonatal rat cardiomyocytes in vitro for up to 14 days and increased the expression of cardiac genes important for muscle contraction, electrical coupling, and cell-to-cell signal transmission (69). Similarly, Zhou et al. have developed a scaffold made up of single-walled CNTs and gelatin hydrogel to support culturing of neonatal rat cardiac cells in vitro. This scaffold was able to inhibit pathological deterioration of the myocardium and enhance cardiac function post-MI (70). Other clinical studies highlighted the importance of having alginate-hydrogel for treating advanced heart failure compared to standard medical therapy. Alginate hydrogel was shown to be more effective than standard medical therapy for improving exercise capacity, symptoms, and clinical status $(71,72)$. In a study by Meslmani et al., PLGA nanoparticles were immobilized on polytetrafluoroethylene (ePTFE) films to develop vascular grafts as a potential vehicle for antithrombotic drugs reducing side effects of thrombosis (73). Ahadian et al. have incorporated polyester with CNTs to make a polymeric scaffold for cardiovascular studies, and they have found that this approach increases the stability and electrical conductivity of the polymeric scaffolds (74). Liu et al. have introduced titanium dioxide $\left(\mathrm{TiO}_{2}\right)$ nanoparticles into the polyethylene glycol (PEG)ylated chitosan hydrogel matrix for CVT repair. This nano-modified hydrogel has induced cell adhesion, organization of cardiomyocytes and improved mechanical and swelling behaviors (75). Finally, Au NPs have been also explored for cardiac tissue engineering due to their numerous advantages, including biocompatibility, chemical stability, intrinsic optical properties, ease of surface functionalization, anti-cardiac hypertrophy effect, high electrical conductivity, and availability in various ways of geometries (i.e., nanospheres, nanorods, nanowires). For example, combining $\mathrm{Au}$ NPs with ECM/silk fibroin has resulted in favorable conductivity, retention of cardiomyocyte survival, increased cell compatibility in vitro, and decreased infarct size in vivo (76). To conclude, several types of biomaterials and nanomaterials offer great opportunities to face challenges related to the treatment of CVDs.

\section{THE POTENTIAL OF 2D MATERIALS IN CARDIOVASCULAR REGENERATION}

CVDs which include the main pathologies such as ischemic heart disease (IHD), stroke, and peripheral ischemic disease, are priority areas for tissue regeneration (77). The current conventional device-based or pharmacological therapies cannot reverse the myocardial function loss. They are limited by the different disease presentations of patients with conduction disorders, such as atrioventricular (AV) block and ventricular arrhythmias (78). As an example, an electronic pacemaker controlling heart pumping function reduces patient mortality and hospitalization, but, the conduction blockage is not solved because non-conductive tissue or an abnormal conductive pathway still exists in the cardiac tissue $(42,79)$. For this reason, conductive biomaterials or nanomaterials could be integrated with the pacemaker to exhibit high electrical conduction of these abnormal ventricle functions (80-82). 
Recently, researchers have been investigating comparatively new 2DMs-based applications for cardiac tissue engineering. To illustrate, Gr is a good candidate for regenerating different tissues with its high specific surface area, porosity, antibacterial activity, and excellent mechanical strength. Gr has been proven to guide and accelerate the differentiation of stem cells like MSCs into specific cell types, including adipocytes, osteoblasts, and chondrocytes, through interactions with chemical inducers such as insulin, which mediates fatty acid synthesis and adipogenesis. Just as in Gr, GO directs stem cell differentiation. This is mainly occurred due to the functional groups on the surface of GO that adsorb ECM proteins. This adsorption of ECM proteins on GO promotes cell adhesion on its surface $(83,84)$. In 2016, many studies about the immunomodulatory effect of Gr were also reported (85). As an implantable biomaterial and scaffold, it interacts with host tissue cells, exerts an intense impact on the immune response of that host, and thus affects cardiac repair. In general, the host innate immune system consists of phagocytic cells such as macrophages, neutrophils, and dendritic cells (DCs). They are introduced as the first line of defense against foreign particles or microorganisms and maintain tissue homeostasis. Gr encounters the cells of the immune system, firstly macrophages secrete inflammatory cytokines like interleukin (IL)-6, and IL-8, and pro-angiogenic factors such as VEGF, and tumor necrosis factor-alpha (TNF- $\alpha$ ). In CVDs, macrophages enhancing pro-inflammatory cytokines are classically activated and thus can be classified under the M1 phenotype. However, they are polarized into alternatively activated M2 phenotypes during cardiac treatment (86). Thus, the general issue is to have novel biomaterials as agents utilizing and modulating the power of macrophages to get an appropriate immune response $(87,88)$. Malanagahalli et al. prepared a fewlayer Gr (FLG) and investigated its biological response on mouse bone marrow-derived macrophages (BMDMs). They found that increased doses of FLG did not hinder the viability of cells, caused no significant secretion of pro-inflammatory cytokines such as IL- 6 and TNF- $\alpha$, and did not evoke inflammatory responses in primary BMDMs (89). It is of interest to note that the current studies to regulate cardiac inflammation include the targeting of other immune cells which take part in adaptive immunity like $\mathrm{B}$ cells, and $\mathrm{T}$ cells or factors including reactive oxygen species (ROS) $(90,91)$. To exemplify, Tomić et al. have investigated the immunomodulatory actions of Gr quantum dots (GQD) in human peripheral blood MNCs. They showed that GQD inhibits the proliferation of the MNCs, reduces the functions of monocyte-derived DCs and the proliferation of T cells while augmenting the production of anti-inflammatory cytokines that are advantageous in studying $\mathrm{T}$ cell-mediated pathologies (92). Moreover, the current in vitro cell differentiation methods, particularly iPSCs derivation, expansion, and differentiation, do not completely mimic the structural properties such as myofibril organization and electrophysiological properties such as conduction velocity of cardiomyocytes. To overcome this, Wang et al. have maintained human iPSCs (hiPSCs) lines on Gr sheets and demonstrated that $\mathrm{Gr}$ sheets with a conductive surface can improve the maturation of hiPSCs derived cardiomyocytes without the need for electrical stimulation. This facilitates cell to cell communication via improved expression levels of connexin 43, a gap junction protein (93). Other GDs especially GO hold great mechanical properties similar to natural cardiac tissues that are undoubtedly suitable for CVT engineering and have been extensively studied in the literature. Accordingly, Park et al. have studied the effects of GO attachment on MSCs prior to MSC transplantation into the infarcted myocardium. This attachment of GO to MSCs protects interactions between MSCs and ECM proteins against ROS-mediated deterioration of cell adhesion and then maintains the survival of MSCs. The transplantation of stem cells without the aid of GO will not be able to result in interaction with ECM owing to the ROS generated in the ischemic myocardium and will eventually die. Thus, this study is highly essential to understand the importance of MSC transplantation with 2D materials (94). Wang et al. have prepared complexes of GO with polyethyleneimine (PEI) or PEG to examine their interactions with mouse monocytemacrophage cells. As a result, both GO-PEI and GO-PEG have very low cytotoxicity toward the mouse cells, and GO-PEG gives rise to a stronger immune response, while GO-PEI displays no obvious stimulation (95). Paul et al. made a nanocomposite hydrogel composed of functionalized GO, DNA $\mathrm{VEGF}$, and gelatin methacryloyl (GelMA) in order to evaluate its therapeutic efficacy for MI in vivo. Authors have shown that the injected hydrogel has enhanced contractile performance, and the injured tissue was repaired without cytotoxicity (96). Bao et al. have combined conductive hydrogel with GO and adipose tissue stem cells (ADSCs) to form PEG/melamine (MEL)/thiol modified hyaluronic acid (HA-SH) hydrogel. Following its injection into the $\mathrm{MI}$ region in a rat model, authors have observed smaller infarct size, thicker left ventricular wall, and higher expression of cardiac genes, $\alpha$-smooth muscle actin ( $\alpha$-SMA) and Cx43, after treatment (97). Saravanan et al. have highlighted that the implantation of GO-Au nanosheets together with chitosan scaffold improves ventricular contractility and function (98). Choe et al. have devised a reduced GO/ alginate microgel to obtain higher therapeutic efficacy and functional infarcted cardiac tissues. They have suggested that the microgel could scavenge ROS, which allowed cardiomyocytes to continue living and functioning even when exposed to $\mathrm{H}_{2} \mathrm{O}_{2}$ (99). Nazari et al. have developed polyurethane (PU)/rGO-Ag nanofibrous scaffolds, which were able to upregulate specific cardiac genes like alpha-MHC, GATA-4, T-box 18, and cTnT (100). Other 2D materials have also been reported to be used in cardiovascular repair and regeneration. For instance, Nazari et al. have combined $\mathrm{MoS}_{2}$ nanosheets with nylon6 nanofibers for cardiac repair. Such an approach has resulted in higher conductivity and better biocompatibility than pure nylon6 (101). In another study, $\mathrm{Ti}_{3} \mathrm{C}_{2} \mathrm{~T}_{\mathrm{x}}$ MXene nanosheets have been shown to create physiologically relevant cardiac patches (CPs) for the treatment of MI (102). In another similar study, MXene $\mathrm{Ti}_{2} \mathrm{C}$ was incorporated into a cryogel resulting in a conductive $\mathrm{CP}$, which was shown to promote functional maturation of cardiomyocytes and enhance repair of myocardial infarction (103). Following the applications of MXenes in the field, MXene quantum dots (QDs) also showed potential in CVT regeneration. In 2019, injection of a hydrogel containing $\mathrm{Ti}_{3} \mathrm{C}_{2} \mathrm{~T}_{\mathrm{x}}$ MXene QDs at an infarct site was 
shown to reduce recruitment of selected immune cells, which are human T-lymphocytes, as well as promote immunosuppressive regulatory T cells, and limit secondary injury to the heart (104). More recently, the same group immune-engineered tantalum carbide $\left(\mathrm{Ta}_{4} \mathrm{C}_{3} \mathrm{~T}_{\mathrm{x}}\right)$ MXene QDs to develop immunomodulatory material that can inhibit desired cellular immune responses during the healing process via regulation of surface co-activator and co-inhibitor molecules. In their report, they have shown that these materials were able to ameliorate the cellular and structural changes of early allograft vasculopathy (105). Such an immune-engineering approach can overcome one of the biggest limitations of CVT engineering in the future.

Overall, $\mathrm{Gr}$ and GDs are among the most popular 2D nanostructures in cardiovascular repair and regeneration according to the literature. Although other 2DMs are being used in bone, skin, and neural tissue regeneration and wound healing, they are attractive to researchers in cardiac tissue therapy (6). Based on their physicochemical characteristics, 2DMs possess intrinsic immunological activities useful in cancer immunotherapy, chronic inflammation, organ transplantation, and autoimmune diseases. They can be recognized by the immune cells, resulting in the activation or suppression of the immune system (85). They can also serve as antioxidant agents preventing ROS-mediated cell stress and death (106). As reported by Gazzi et al., various groups have spent efforts to obtain qualitative and quantitative immune characterization and to define immune profiles of Gr, GDs, and other carbon-based nanomaterials (107). Furthermore, the interactions of GDs or MXenes with immune cells have been demonstrated as advantageous for tissue regeneration. Thus, it is essential to consider the physicochemical characterization and immunomodulatory properties for evaluating the applicability of $2 \mathrm{D}$ materials in cardiac tissue engineering.

\section{FUTURE PERSPECTIVES}

CVDs emerge and affect many people worldwide, and thus cardiovascular repair and regeneration via cell therapy have progressed within the past decade. Many researchers have studied and tested the efficacy of using stem cells together with biocompatible biomaterials or nanomaterials to treat CVDs (108-110). Over the last years, unique 2DMs showing similar electrical and mechanical properties to native myocardium have been studied to achieve successful therapies. However, in vivo behavior and interaction mechanism of $2 \mathrm{DMs}$ with biomolecules, degradation profile, long-term safety, and hardto-control fabrication process have not been fully optimized yet $(4,6)$. On the other hand, various groups have emphasized the importance of material properties which directly determine their behavior in the biological environment, including toxicity and degradation profiles (111). For this reason, by controlling surface chemistry, shape, and size, we can make them safe and effective helpers of cellular therapies for CVDs. All materials mentioned in this review harbor important properties for cardiac tissue repair and regeneration. Table 1 summarizes different studies performed in the field, and discusses advantages and limitations of each study. Each of these materials could improve a certain function, even if they sometimes elicit multiple actions. In particular, among 2D materials, $\mathrm{Gr}$ and $\mathrm{GO}$ have been shown to be potential platforms for stem cell delivery, adhesion, growth, and differentiation through their adsorption capacity for hydrophobic and electrostatic interactions. BP has been reported to be highly electrically conductive, induce a lowROS microenvironment, and restore angiogenesis, as well as neurogenesis, but no studies have reported its integration and the direct action mechanisms on cardiomyocytes. Whereas, another 2D material $\mathrm{MoS}_{2}$ is used for its good cytocompatibility and its ability to conduct electrical signals. MXenes are used for the modulation of the immune response, and improvement of cardiac differentiation.

For good therapeutic results, it is vital to find the best way of transferring cells along with the nanomaterials to the infarcted cardiac tissues without any or minimal conduction abnormalities. This can be achieved by considering and optimizing conditions such as duration of disease (acute or chronic disorder), the number of transplanted cells, sex, and patient age $(9,42)$. The matrix should resemble the myocardial architecture to control the maturation stages better and develop highly efficient models limiting scar tissue formation. For this purpose, studies have been performed with nanofibrous PLLA scaffolds for vascular regeneration. Human and mouse-derived iPSC-derived smooth muscle cells (SMCs) have been seeded onto a 3D macro-porous and nanofibrous PLLA scaffolds. This seeding process maintains the maturation of in vitro iPSCderived SMCs by inducing functional contractile phenotype and promotes in vivo vascular structure formation (125127). Furthermore, immense studies are required to face challenges related to selected cell types or combinations and electromechanical stimulation $(41,42)$. Apart from this, new engineering technologies might allow three-dimensional (3D) bioprinting of biomaterials and even the building of 3D cardiac tissues that can be directly transplanted to the damaged area. As an example, Ho et al. have already printed a polycaprolactone (PCL) scaffold using a microextrusion 3D printer and modified it with polycaprolactone CNT for cardiac tissue engineering. This composite scaffold made of PCL and polycaprolactone CNT better enhances cell proliferation and improves cardiomyoblast viability compared to non-modified PCL scaffold (128). Maiullari et al. have presented an innovative 3D bioprinting approach for vascularized cardiac tissue engineering. They have printed human umbilical vein endothelial cells (HUVECs) and iPSCderived cardiomyocytes in various geometries. To encapsulate this multi-cellular construct, they have utilized an alginate/PEGfibrinogen hydrogel scaffold owing to its enhanced capacity for damaged cardiac repair. As a result, they have demonstrated the feasibility of the construct for enabling the maturation of the cells into functional vascularized tissue in the heart (129). Basara et al. have shown that when $\mathrm{Ti}_{3} \mathrm{C}_{2} \mathrm{~T}_{\mathrm{x}}$ MXene nanosheets were bio-printed together with PEG, they can improve synchronous beating and conduction velocity during cardiomyocyte differentiation (102). Bioprinting applications have shown success in the regeneration of various other tissues. Yang et al. have implemented photothermal therapy 


\begin{tabular}{|c|c|c|c|c|c|c|c|}
\hline & Composition & Model & Cell & Disorder & Advantage & Limitation & References \\
\hline $\mathrm{Gr}$ & $\begin{array}{l}\text { With and without } \\
\text { oxygen plasma }\end{array}$ & in vitro & $\begin{array}{l}\text { hiPSCs-derived } \\
\text { cardiomyocytes (CMs) }\end{array}$ & Not specified & $\begin{array}{l}\text { * Low cost, robust, and flexible } \\
\text { * Biomimetic conductive surface } \\
\text { * Increased Cx43 expression and } \\
\text { electrical propagation } \\
\text { * Enhanced } \mathrm{Ca}^{2+} \text { handling } \\
\text { * Effective hiPSCs differentiation into } \\
\text { CMs, and CMs maturation } \\
\text { * Increased BMP signaling during } \\
\text { cardiogenesis } \\
\text { * Cx43 = cardiac gene important } \\
\text { for electrical conduction }\end{array}$ & $\begin{array}{l}\text { * Reduced conductivity and elevated } \\
\text { BMP signaling via oxygen plasma } \\
\text { modification } \\
\text { * Only two-fold increase in } \\
\text { conduction velocity, correlated with } \\
\text { Cx43 gene expression }\end{array}$ & (93) \\
\hline \multirow[t]{3}{*}{ GO } & None & $\begin{array}{l}\text { in vitro ROS } \\
\text { presentation and in vivo } \\
\text { implantation }\end{array}$ & MSCs & Myocardial ischemia & $\begin{array}{l}\text { * Non-significant toxicity } \\
\text { * Enhanced MSCs adhesion via ECM } \\
\text { protein adsorption on GO } \\
\text { * Increased MSCs survival rate even } \\
\text { under ROS presence } \\
\text { * High number of engrafted MSCs } \\
\text { * Improved paracrine factors } \\
\text { secretion from MSCs } \\
\text { * Reduced cardiac tissue apoptosis } \\
\text { by promoting angiogenesis } \\
\text { * Improved cardiac therapy }\end{array}$ & $\begin{array}{l}\text { * Long-time retention of GO } \\
\text { post-implantation in vivo }\end{array}$ & (94) \\
\hline & poly-L-lysine (PLL) & in vitro & $\begin{array}{l}\text { 3T3 fibroblasts, CMs, } \\
\text { ECs, and hMSCs }\end{array}$ & Not specified & $\begin{array}{l}\text { * Suitable interface material } \\
\text { * Strong cell-cell electrical coupling } \\
\text { between layers via the adhesive thin } \\
\text { film structure } \\
\text { * Strong spontaneous beating } \\
\text { * Stably organized 3D-engineered } \\
\text { cardiac tissue } \\
\text { * Improved cardiac cell maturation } \\
\text { * Enhanced biological activity via PLL } \\
\text { and mechanical integrity via GO }\end{array}$ & $\begin{array}{l}\text { * Decreased conductivity with PLL } \\
\text { functionalization at the beginning } \\
\text { (before its degradation) } \\
\text { * Decreased cell viability with } \\
\text { increased number of layers } \\
\text { * Cytotoxicity of cationic PLL at high } \\
\text { concentrations }\end{array}$ & (112) \\
\hline & PEI/DNAVEGF/GelMA & $\begin{array}{l}\text { Both in vitro and } \\
\text { * in vivo (rats) }\end{array}$ & $\begin{array}{l}\text { HUVECs, and } \\
\text { embryonic rat CMs } \\
\text { (H9c2) }\end{array}$ & Acute Ml & $\begin{array}{l}\text { * Biocompatible } \\
\text { * Non-significant toxicity even in } \\
\text { long-time post-administration } \\
\text { * Supported microvasculature and } \\
\text { endothelial cord formation via } \\
\text { GelMA } \\
\text { * Effective in vivo gene transferring } \\
\text { via PEI } \\
\text { * Proangiogenic activities via } \\
\text { DNAvEGF in vitro } \\
\text { * Increased myocardial capillary } \\
\text { density } \\
\text { * Reduced scar size }\end{array}$ & $\begin{array}{l}\text { * Unknown salutary effects of multiple } \\
\text { administration of the functionalized } \\
\text { GO on cardiac functioning }\end{array}$ & (96) \\
\hline
\end{tabular}




\begin{tabular}{|c|c|c|c|c|c|c|}
\hline Composition & Model & Cell & Disorder & Advantage & Limitation & References \\
\hline PEG-MEL/HA-SH & $\begin{array}{l}\text { Both in vitro and in vivo } \\
\text { (SD male rats) }\end{array}$ & ADSCs & Ml & $\begin{array}{l}\text { * Superior therapeutic efficacy with } \\
\text { very high cytocompatibility } \\
\text { * Very soft mechanical property via } \\
\text { flexible PEG } \\
\text { * Anti-fatigue, stable, and conductive } \\
\text { property close to native } \\
\text { myocardium via GO } \\
\text { * Faster gelation process via } \\
\text { PEG-MEL/HA-SH } \\
\text { * Resistant to dynamic stress } \\
\text { * Effective electromechanical signal } \\
\text { transmission with cell-cell } \\
\text { communication, } \\
\text { * Enhanced Cx43 and } \alpha \text {-SMA } \\
\text { expression } \\
\text { * Higher vessel density and ejection } \\
\text { fraction } \\
\text { * Reduced fibrosis area } \\
\text { * Thicker left ventricular wall }\end{array}$ & $\begin{array}{l}{ }^{*} \text { A comparatively small reduction in } \\
\text { the infarction size than the study by } \\
\text { Wang et al. (113) }\end{array}$ & (97) \\
\hline $\begin{array}{l}\text { OligoPEG fumarate } \\
\text { (OPF) }\end{array}$ & $\begin{array}{l}\text { Both in vitro and in vivo } \\
\text { (rats) }\end{array}$ & Mouse ESCs, CMs & Ml & $\begin{array}{l}\text { * Improved in vitro cell attachment } \\
\text { * Enhanced mechanical support, } \\
\text { cytoskeletal structure and electrical } \\
\text { signal propagation } \\
\text { * Enhanced } \mathrm{Ca}^{2+} \text { signal conduction } \\
\text { of CMs in the infarcted area } \\
\text { * Better heart functioning via } \\
\text { increased intercalated disc } \\
\text { formation } \\
\text { * Promoted Cx43 expression, and } \\
\text { macrophage activation with } \\
\text { increased CD68+ cells ratio }\end{array}$ & $\begin{array}{l}\text { * GO alone may not be used as a } \\
\text { carrier of mouse ESCs } \\
\text { * OPF alone is non-conductive, } \\
\text { which may not restore impulse } \\
\text { propagation }\end{array}$ & (114) \\
\hline Au-Chitosan & $\begin{array}{l}\text { in vitro, ex-vivo and in } \\
\text { vivo (male Wistar rats) }\end{array}$ & $\begin{array}{l}\text { iPSCs-derived CMs, rat } \\
\text { smooth muscle cells, } \\
\text { mouse fibroblasts, }\end{array}$ & & $\begin{array}{l}\text { * Two-fold increased conductivity via } \\
\text { Au } \\
\text { * Enhanced conduction velocity and } \\
\text { cardiac contractility in infarcted area } \\
\text { * Restored ventricular function } \\
\text { * No immune response in the } \\
\text { myocardium (unchanged numbers } \\
\text { of } \\
{ }^{*} \text { CD4+ and CD8+T cells) }\end{array}$ & $\begin{array}{l}\text { * Lack of electrical conductivity in } \\
\text { chitosan } \\
\text { * Aggregation of Au in the chitosan } \\
\text { microstructures, causing stress and } \\
\text { damage on tissue }\end{array}$ & (98) \\
\hline
\end{tabular}




\begin{tabular}{|c|c|c|c|c|c|c|}
\hline Composition & Model & Cell & Disorder & Advantage & Limitation & References \\
\hline \multirow[t]{2}{*}{ Chitosan } & (1) in vitro & $\begin{array}{l}\text { hESC-derived } \\
\text { fibroblasts, and CMs }\end{array}$ & Not specified & $\begin{array}{l}\text { * Enhanced cell viability and } \\
\text { proliferation } \\
\text { * Rapid self-healing property }\end{array}$ & $\begin{array}{l}\text { * Very brittle pure chitosan, } \\
\text { * Decreased adhesive strength of } \mathrm{GO} \\
\text { at } 0.75 \text { and } 1 \mathrm{mg} / \mathrm{mL}\end{array}$ & (115) \\
\hline & 2)in vitro & $\mathrm{H} 9 \mathrm{c} 2$ & & $\begin{array}{l}\text { * Swelling, porosity, and conductive } \\
\text { properties } \\
\text { * Increased cTnT expression as well } \\
\text { as Cx43 without exogeneous } \\
\text { electrical stimulation, Large } \\
\text { amounts of ECM secretion } \\
\text { * Supported cell adhesion and } \\
\text { extension } \\
\text { * cTnT= cardiac Troponin T, gene } \\
\text { important for contractile } \\
\text { function }\end{array}$ & $\begin{array}{l}\text { * Decreased porosity and cell viability } \\
\text { with GO concentration in } 600 \mathrm{mg} / \mathrm{L} \\
\text { of the scaffold }\end{array}$ & (116) \\
\hline $\begin{array}{l}\text { Polyethylene } \\
\text { terephtha-late (PET) }\end{array}$ & in vitro & HUVECs, and H9c2 & Not specified & $\begin{array}{l}\text { * Potential electroconductive CP } \\
\text { * Almost two-fold increase in } \\
\text { mechnical behavior } \\
\text { * Improved wettability } \\
\text { * Controlled cellular behaviors, cell } \\
\text { attachment, and spreading } \\
\text { * Guaranteed cardiac cell support for } \\
\sim 2 \text { months }\end{array}$ & $\begin{array}{l}\text { * Unsupported elongated cell } \\
\text { morphology of PET without GO } \\
\text { * Unmonitored long-term degradation } \\
\text { rate and process of the CP }\end{array}$ & (118) \\
\hline $\begin{array}{l}\text { Reverse Thermal Gel } \\
\text { (RTG) }\end{array}$ & in vitro & $\begin{array}{l}\text { Neonatal rat ventricular } \\
\text { myocytes (NRMs) }\end{array}$ & Not specified & $\begin{array}{l}\text { * Temperature-dependent changes } \\
\text { from 2D gelation to 3D matrix gel } \\
\text { * Negligibly invasive system with low } \\
\text { viscosity } \\
\text { * Better cell proliferation, alignment, } \\
\text { maturation and long-time survival } \\
\text { * Non-cytotoxicity }\end{array}$ & $\begin{array}{l}\text { * High conducting resistance of RTG } \\
\text { alone } \\
\text { * Non-increased number of } \alpha \text {-actinin } \\
\text { positive cells until } 7^{\text {th }} \text { day of culturing }\end{array}$ & (119) \\
\hline Gelatin & in vitro & NRMs & Not specified & $\begin{array}{l}\text { * Long-term functional CM culturing } \\
\text { * Stiffness similat to native } \\
\text { myocardium via GO } \\
\text { * Longest sarcomere length on 3rd } \\
\text { day culturing } \\
\text { * Promoted beating velocity via GO } \\
\text { * Better cell alignment and } \\
\text { synchronous contraction via } \\
\text { micropatterning }\end{array}$ & $\begin{array}{l}\text { * Very soft, physically non-stable, and } \\
\text { thermosensitivity properties of } \\
\text { gelatin alone }\end{array}$ & \\
\hline
\end{tabular}


TABLE 1 | Continued

\begin{tabular}{|c|c|c|c|c|c|c|c|}
\hline & Composition & Model & Cell & Disorder & Advantage & Limitation & References \\
\hline \multirow[t]{7}{*}{$\mathrm{rGO}$} & Fibronectin & $\begin{array}{l}\text { Both in vitro and in vivo } \\
\text { (mouse) }\end{array}$ & MSCs & $\mathrm{Ml}$ & $\begin{array}{l}\text { * Enhanced cell-ECM interactions, } \\
\text { angiogenic growth factor } \\
\text { expression, and Cx43 upregulation } \\
\text { * Increased MSC function via } \\
\text { electrical conductivity of rGO } \\
\text { * Higher ejection fraction and better } \\
\text { cardiac performance in vivo }\end{array}$ & $\begin{array}{l}\text { * Limited cell-ECM interactions, and } \\
\text { growth factor expression in MSCs } \\
\text { alone } \\
\text { * Induced cell stress and } \\
\text { apoptosis with GO above } 10 \mu \mathrm{g} / \mathrm{mL}\end{array}$ & (120) \\
\hline & GelMA & in vitro & rat $\mathrm{CMs}$ & Not specified & $\begin{array}{l}\text { * Higher cell retention, stronger } \\
\text { contractility and faster spontaneous } \\
\text { beating rate compared to } \\
\text { GO-GelMA }\end{array}$ & $\begin{array}{l}\text { * Limited thickness of the } \\
\text { functionalized hydrogel via rGO } \\
\text { concentration }\end{array}$ & (121) \\
\hline & $\mathrm{PU}$ and $\mathrm{Ag}$ & in vitro & hCPCs & Not specified & $\begin{array}{l}\text { * Upregulation of GATA-4, T-box 18, } \\
\text { and cTnT } \\
\text { * Increased tensile strength, } \\
\text { wettability, and electrical } \\
\text { conductivity via rGO-Ag } \\
\text { * Induced cardiogenic differentiation } \\
\text { via rGO }\end{array}$ & $\begin{array}{l}\text { * Non-efficient electrical conductivity } \\
\text { of PU alone } \\
\text { * Cytotoxicity of Ag without rGO }\end{array}$ & (100) \\
\hline & Alginate & $\begin{array}{l}\text { Both in vitro and in vivo } \\
\text { (rats) }\end{array}$ & $\begin{array}{l}\text { MSCs, and neonatal rat } \\
\text { CMs }\end{array}$ & Acute MI & $\begin{array}{l}\text { * High cell protection capacity } \\
\text { * Increased cell viability under } \mathrm{H}_{2} \mathrm{O}_{2} \\
\text { stress via superior antioxidizing } \\
\text { activity of } \mathrm{rGO} \\
\text { * Enhanced MSCs delivery, and } \\
\text { cardiac function }\end{array}$ & $\begin{array}{l}\text { * Low viability and function of } \\
\text { MSCs alone due to harsh conditions }\end{array}$ & (99) \\
\hline & Collagen & in vitro & HUVECs, and CMs & $\begin{array}{l}\text { Infective endocarditis } \\
\text { (IE) }\end{array}$ & $\begin{array}{l}\text { * Electroactive CP } \\
\text { * Electrical coupling (Cx43), muscle } \\
\text { contraction, relaxation (cTnT) and } \\
\text { cytoskeleton alignment ( } \alpha \text {-actinin4) } \\
\text { after } 7 \text { days } \\
\text { * Promising antibacterial activity for } \\
\text { preventing IE }\end{array}$ & $\begin{array}{l}\text { * Decreased pore size of collagen } \\
\text { scaffold and possible cytotoxicity } \\
\text { with increased rGO concentration }\end{array}$ & (122) \\
\hline & $\begin{array}{l}\text { Polyester amide } \\
\text { (PEA)-Chitosan }\end{array}$ & in vitro & $\begin{array}{l}10 \text { T1/2 cells, and } \\
\text { iPSC-derived MSCs }\end{array}$ & Not specified & $\begin{array}{l}\text { * Increased PEA porosity via } \\
\text { ultrasonication and leaching of } \\
\text { PEO/PEA } \\
\text { * Lowering of the required voltage for } \\
\text { electrospinning via rGO } \\
\text { * Supported cardiac differentiation } \\
\text { * Non-cytotoxicity }\end{array}$ & $\begin{array}{l}\text { * Limited cell infiltration and tissue } \\
\text { maturation of electrospun PEA } \\
\text { alone } \\
\text { * Slightly less conductive effect of } \\
\text { PEA-rGO with chitosan }\end{array}$ & (123) \\
\hline & Gellan gum & in vitro & $\mathrm{H} 9 \mathrm{c} 2$ & Not specified & $\begin{array}{l}\text { * Higher compressive modulus, and } \\
\text { water-swelling ratio via rGO } \\
\text { * Suitable injectability } \\
\text { * Promising candidate of cardiac } \\
\text { repair with 2wt\% rGO }\end{array}$ & $\begin{array}{l}\text { * Insignificant increase in } \\
\text { compressive strength, ductility, and } \\
\text { degradation }\end{array}$ & (124) \\
\hline
\end{tabular}


TABLE 1 | Continued

\begin{tabular}{|c|c|c|c|c|c|c|c|}
\hline & Composition & Model & Cell & Disorder & Advantage & Limitation & References \\
\hline TMDs & $\mathrm{MoS}_{2} / \mathrm{Nylon} 6$ & in vitro & $\begin{array}{l}\text { Mouse embryonic } \\
\text { cardiac cells (mECCs) }\end{array}$ & Not specified & $\begin{array}{l}\text { * Better cell elongation and } \\
\text { differentiation on the scaffold via } \\
\text { MoS }_{2} \\
\text { * Upregulation of cardiac genes, } \\
\text { which are GATA-4, c-TnT, Nkx } 2.5 \\
\text { and } \alpha-M H C \\
\text { * } \sim 4 \text { fold increase in electrical } \\
\text { conductivity via MoS } \\
\text { * Mechanical support via Nylon6 } \\
\text { * Increased fracture modulation and } \\
\text { decreased modulus via } \mathrm{MoS}_{2}\end{array}$ & $\begin{array}{l}\text { * Lack of electrical conductivity } \\
\text { property of Nylon6 alone } \\
\text { * Decreased Nylon6 wettability with } \\
\mathrm{MoS}_{2} \text { presence }\end{array}$ & (101) \\
\hline \multirow[t]{2}{*}{ MXenes } & $\begin{array}{l}\mathrm{Ti}_{2} \mathrm{CT}_{x} / \text { PEGdiacrylate } \\
\text { (PEGDA)/ GelMA } \\
\left.\text { ( } \mathrm{Ti}_{2} \mathrm{C}-\mathrm{cryogel}\right)\end{array}$ & $\begin{array}{l}\text { Both in vitro and in vivo } \\
\text { (SD rats) }\end{array}$ & $\begin{array}{l}\text { Rat aortic endothelial } \\
\text { cells (rAECs), and } \\
\text { neonatal rat CMs }\end{array}$ & $\mathrm{Ml}$ & $\begin{array}{l}\text { * Hydrophilic, elastic and conductive } \\
\text { CP } \\
\text { * Induced tube structure formation of } \\
\text { ECs } \\
\text { * Obvious left ventricle anterior wall } \\
\text { activity } \\
\text { * Recruited macrophages and } \\
\text { released TGF- } \beta \\
\text { * Improved cardiac function and scar } \\
\text { formation } \\
\text { * Promoted in vivo vascularization }\end{array}$ & $\begin{array}{l}\text { * Very low conductivity of } \mathrm{MATT}_{2} \mathrm{C} \\
\text { * Low mechanical strength and } \\
\text { toughness of pure cryogel }\end{array}$ & (103) \\
\hline & $\mathrm{Ti}_{3} \mathrm{C}_{2} \mathrm{~T}_{x} / \mathrm{PEG}$ & in vitro & hiPSCs-derived CMs & Ml & $\begin{array}{l}\text { * } 3 \text { D printed CP with high } \\
\text { electroconductivity and fibrillar } \\
\text { structure } \\
\text { * Promoted cell viability, and } \\
\text { alignment } \\
\text { * Better coordinated cell network } \\
\text { * Significant increase in MYH7, } \\
\text { SERCA2, and TNNT2 expression } \\
\text { with increased cell maturity } \\
\text { * Improved beating cell area } \\
\text { percentage, and conduction } \\
\text { velocity } \\
\text { * Low protein adsorption property of } \\
\text { PEG }\end{array}$ & $\begin{array}{l}\text { * Slightly decreased sarcomere } \\
\text { length on the construct via } \mathrm{Ti}_{3} \mathrm{C}_{2} \mathrm{~T}_{\mathrm{x}} \\
\text { * Non-observable gene upregulation } \\
\text { effect at the protein level } \\
\text { * Insignificant improvement in the } \\
\text { beating rate of the CMs }\end{array}$ & (102) \\
\hline MXene QDs & $\mathrm{Ti}_{3} \mathrm{C}_{2} \mathrm{~T}_{x} /$ Chitosan & in vitro & $\begin{array}{l}\text { Bone marrow MSCs, } \\
\text { and iPSCs-derived } \\
\text { fibroblasts }\end{array}$ & Not specified & $\begin{array}{l}\text { * } 3 \text { D platform with stretchable, and } \\
\text { flexible shape memory properties } \\
\text { * Increased electrical signal } \\
\text { transmission } \\
\text { * Supported cell survival and } \\
\text { proliferation } \\
\text { * Maintained injectability and } \\
\text { thermosensitivity } \\
\text { * Promoted immune tolerance, and } \\
\text { decreased T-cell dependent } \\
\text { inflammatory response }\end{array}$ & $\begin{array}{l}\text { * Smaller swelling degrees of } \\
\text { Chitosan alone }\end{array}$ & (104) \\
\hline
\end{tabular}

Ti2 (PEGDA)/ GelMA (SD rats) cells (rAECs), and ( $\mathrm{Ti}_{2} \mathrm{C}$-cryogel) neonatal rat CMs

matory response 

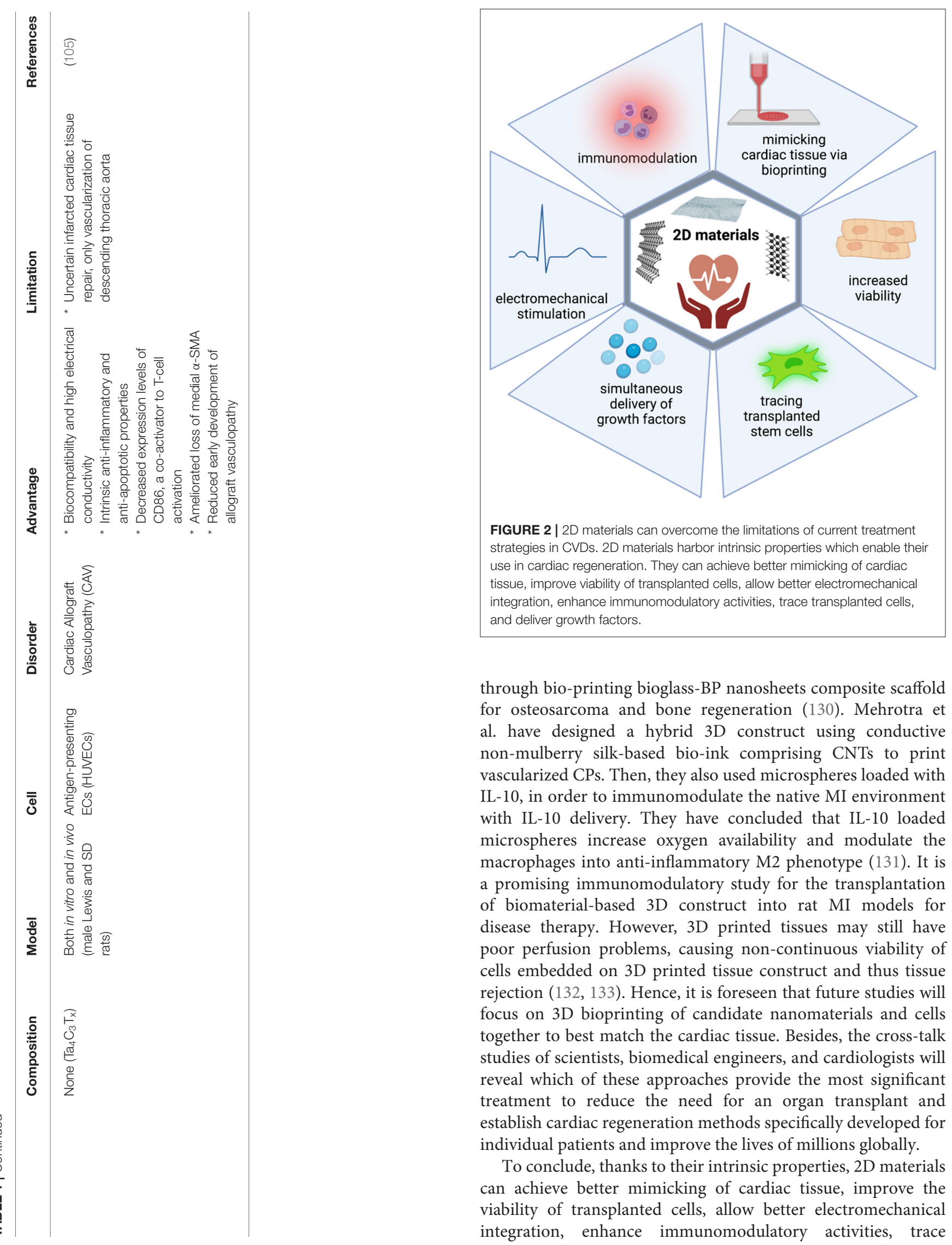

through bio-printing bioglass-BP nanosheets composite scaffold for osteosarcoma and bone regeneration (130). Mehrotra et al. have designed a hybrid $3 \mathrm{D}$ construct using conductive non-mulberry silk-based bio-ink comprising CNTs to print vascularized CPs. Then, they also used microspheres loaded with IL-10, in order to immunomodulate the native MI environment with IL-10 delivery. They have concluded that IL-10 loaded microspheres increase oxygen availability and modulate the macrophages into anti-inflammatory M2 phenotype (131). It is a promising immunomodulatory study for the transplantation of biomaterial-based $3 \mathrm{D}$ construct into rat $\mathrm{MI}$ models for disease therapy. However, 3D printed tissues may still have poor perfusion problems, causing non-continuous viability of cells embedded on 3D printed tissue construct and thus tissue rejection $(132,133)$. Hence, it is foreseen that future studies will focus on $3 \mathrm{D}$ bioprinting of candidate nanomaterials and cells together to best match the cardiac tissue. Besides, the cross-talk studies of scientists, biomedical engineers, and cardiologists will reveal which of these approaches provide the most significant treatment to reduce the need for an organ transplant and establish cardiac regeneration methods specifically developed for individual patients and improve the lives of millions globally.

To conclude, thanks to their intrinsic properties, 2D materials can achieve better mimicking of cardiac tissue, improve the viability of transplanted cells, allow better electromechanical integration, enhance immunomodulatory activities, trace 
transplanted cells, and deliver growth factors (Figure 2). Therefore, it is clear that as new members of the $2 \mathrm{D}$ materials are explored, they will quickly become part of cardiac tissue engineering technologies.

\section{AUTHOR CONTRIBUTIONS}

AY coordinated the study. CGo and CGu performed literature search. All authors wrote the manuscript. All

\section{REFERENCES}

1. Rezaie HR, Bakhtiari L, Öchsner A. Biomaterials and Their Applications. Cham: Springer (2015). doi: 10.1007/978-3-319-17846-2

2. Kiran ASK, Ramakrishna S. An Introduction to Biomaterials Science and Engineering. Singapore: World Scientific (2021). doi: 10.1142/12038

3. Bose S, Bandyopadhyay A. Introduction to biomaterials. In: Bandyopadhyay A, Bose S, editors. Characterization of Biomaterials. Elsevier (2013). p. 1-9. doi: 10.1016/B978-0-12-415800-9.00001-2

4. Zheng $\mathrm{Y}$, Hong $\mathrm{X}$, Wang J, Feng L, Fan T, Guo R, et al. 2D nanomaterials for tissue engineering and regenerative nanomedicines: recent advances and future challenges. Adv Healthcare Mater. (2021) 10:2001743. doi: 10.1002/adhm.202001743

5. Kurapati R, Kostarelos K, Prato M, Bianco A. Biomedical uses for 2D materials beyond graphene: current advances and challenges ahead. $A d v$ Mater. (2016) 28:6052-74. doi: 10.1002/adma.201506306

6. Zhang J, Chen $\mathrm{H}$, Zhao $\mathrm{M}$, Liu $\mathrm{G}$, Wu J. 2D nanomaterials for tissue engineering application. Nano Res. (2020) 13:201934. doi: 10.1007/s12274-020-2835-4

7. Ji ST, Kim H, Yun J, Chung JS, Kwon S-M. Promising therapeutic strategies for mesenchymal stem cell-based cardiovascular regeneration: from cell priming to tissue engineering. Stem Cells Int. (2017) 2017:3945403. doi: 10.1155/2017/3945403

8. Cohn JN, Ferrari R, Sharpe N. Cardiac remodeling-concepts and clinical implications: a consensus paper from an international forum on cardiac remodeling. J Am Coll Cardiol. (2000) 35:569-82. doi: 10.1016/S0735-1097(99)00630-0

9. Majka M, Sułkowski M, Badyra B, Musiałek P. Concise review: mesenchymal stem cells in cardiovascular regeneration: emerging research directions and clinical applications. Stem Cells Transl Med. (2017) 6:1859-67. doi: 10.1002/sctm.16-0484

10. Mozaffarian D, Benjamin EJ, Go AS, Arnett DK, Blaha MJ, Cushman $M$, et al. Heart disease and stroke statistics-2015 update: a report from the American Heart Association. Circulation. (2015) 131:e29322. doi: 10.1161/CIR.0000000000000152

11. Cardiovascular Diseases (CVDs) [Online]. World Health Organization (2021). Available online at: https://www.who.int/news-room/fact-sheets/ detail/cardiovascular-diseases-(cvds) (accessed September 13, 2021).

12. Segers VF, Lee RT. Stem-cell therapy for cardiac disease. Nature. (2008) 451:937-42. doi: 10.1038/nature06800

13. Pittenger MF, Mackay AM, Beck SC, Jaiswal RK, Douglas R, Mosca JD, et al. Multilineage potential of adult human mesenchymal stem cells. Science. (1999) 284:143-7. doi: 10.1126/science.284.5411.143

14. Ullah I, Subbarao RB, Rho GJ. Human mesenchymal stem cells-current trends and future prospective. Biosci Rep. (2015) 35:e00191. doi: 10.1042/BSR20150025

15. Jin HJ, Bae YK, Kim M, Kwon S-J, Jeon HB, et al. Comparative analysis of human mesenchymal stem cells from bone marrow, adipose tissue, and umbilical cord blood as sources of cell therapy. Int $J$ Mol Sci. (2013) 14:17986-8001. doi: 10.3390/ijms14091 7986

16. Patel DM, Shah J, Srivastava AS. Therapeutic potential of mesenchymal stem cells in regenerative medicine. Stem Cells Int. (2013) 2013:496218. doi: $10.1155 / 2013 / 496218$ authors contributed to the article and approved the submitted version.

\section{ACKNOWLEDGMENTS}

AY would like to acknowledge the Turkish Academy of Sciences (TUBA) for financial support under the young investigator programme. Figures 1, 2 were created with BioRender.com.

17. Milani-Nejad N, Janssen PM. Small and large animal models in cardiac contraction research: advantages and disadvantages. Pharmacol Therapeut. (2014) 141:235-49. doi: 10.1016/j.pharmthera.2013.10.007

18. Hashimoto H, Olson EN, Bassel-Duby R. Therapeutic approaches for cardiac regeneration and repair. Nat Rev Cardiol. (2018) 15:585600. doi: 10.1038/s41569-018-0036-6

19. Maggini J, Mirkin G, Bognanni I, Holmberg J, Piazzón IM, Nepomnaschy I, et al. Mouse bone marrow-derived mesenchymal stromal cells turn activated macrophages into a regulatory-like profile. PLoS ONE. (2010) 5:e9252. doi: 10.1371/journal.pone.0009252

20. Van Den Akker F, De Jager S, Sluijter J. Mesenchymal stem cell therapy for cardiac inflammation: immunomodulatory properties and the influence of toll-like receptors. Med Inflamm. (2013) 2013:181020. doi: 10.1155/2013/181020

21. Suncion VY, Ghersin E, Fishman JE, Zambrano JP, Karantalis V, Mandel N, et al. Does transendocardial injection of mesenchymal stem cells improve myocardial function locally or globally? An analysis from the Percutaneous Stem Cell Injection Delivery Effects on Neomyogenesis (POSEIDON) randomized trial. Circ Res. (2014) 114:1292-301. doi: 10.1161/CIRCRESAHA.114.302854

22. Rodrigo SF, Van Ramshorst J, Hoogslag GE, Boden H, Velders MA, Cannegieter SC, et al. Intramyocardial injection of autologous bone marrowderived ex vivo expanded mesenchymal stem cells in acute myocardial infarction patients is feasible and safe up to 5 years of follow-up. J Cardiovasc Transl Res. (2013) 6:816-25. doi: 10.1007/s12265-013-9507-7

23. Houtgraaf JH, Den Dekker WK, Van Dalen BM, Springeling T, De Jong R, Van Geuns RJ, et al. First experience in humans using adipose tissue-derived regenerative cells in the treatment of patients with STsegment elevation myocardial infarction. J Am Coll Cardiol. (2012) 59:53940. doi: 10.1016/j.jacc.2011.09.065

24. Gao LR, Chen Y, Zhang NK, Yang XL, Liu HL, Wang ZG, et al. Intracoronary infusion of Wharton's jelly-derived mesenchymal stem cells in acute myocardial infarction: double-blind, randomized controlled trial. BMC Med. (2015) 13:162. doi: 10.1186/s12916-015-0399-z

25. Musialek P, Mazurek A, Jarocha D, Tekieli L, Szot W, Kostkiewicz M, et al. Myocardial regeneration strategy using Wharton's jelly mesenchymal stem cells as an off-the-shelf 'unlimited'therapeutic agent: results from the Acute Myocardial Infarction First-in-Man Study. Adv Int Cardiol. (2015) 11:100. doi: 10.5114/pwki.2015.52282

26. Makkar RR, Smith RR, Cheng K, Malliaras K, Thomson LE, Berman D, et al. Intracoronary cardiosphere-derived cells for heart regeneration after myocardial infarction (CADUCEUS): a prospective, randomised phase 1 trial. Lancet. (2012) 379:895-904. doi: 10.1016/S0140-6736(12)60195-0

27. Malliaras K, Makkar RR, Smith RR, Cheng K, Wu E, Bonow RO, et al. Intracoronary cardiosphere-derived cells after myocardial infarction: evidence of therapeutic regeneration in the final 1-year results of the CADUCEUS trial (CArdiosphere-Derived aUtologous stem CElls to reverse ventricUlar dySfunction). J Am Coll Cardiol. (2014) 63:11022. doi: 10.1016/j.jacc.2013.08.724

28. Hare JM, Fishman JE, Gerstenblith G, Velazquez DLD, Zambrano JP, Suncion VY, et al. Comparison of allogeneic vs autologous bone marrowderived mesenchymal stem cells delivered by transendocardial injection in patients with ischemic cardiomyopathy: the POSEIDON randomized trial. JAMA. (2012) 308:2369-79. doi: 10.1001/jama.2012.25321 
29. Heldman AW, Difede DL, Fishman JE, Zambrano JP, Trachtenberg $\mathrm{BH}$, Karantalis V, et al. Transendocardial mesenchymal stem cells and mononuclear bone marrow cells for ischemic cardiomyopathy: the TAC-HFT randomized trial. JAMA. (2014) 311:62-73. doi: 10.1001/jama.2013.282909

30. Karantalis V, Difede DL, Gerstenblith G, Pham S, Symes J, Zambrano JP, et al. Autologous mesenchymal stem cells produce concordant improvements in regional function, tissue perfusion, and fibrotic burden when administered to patients undergoing coronary artery bypass grafting: the Prospective Randomized Study of Mesenchymal Stem Cell Therapy in Patients Undergoing Cardiac Surgery (PROMETHEUS) trial. Circ Res. (2014) 114:1302-10. doi: 10.1161/CIRCRESAHA.114.303180

31. Meyer GP, Wollert KC, Lotz J, Steffens J, Lippolt P, Fichtner S, et al. Intracoronary bone marrow cell transfer after myocardial infarction: eighteen months' follow-up data from the randomized, controlled BOOST (BOne marrOw transfer to enhance STelevation infarct regeneration) trial. Circulation. (2006) 113:128794. doi: 10.1161/CIRCULATIONAHA.105.575118

32. Behfar A, Crespo-Diaz R, Terzic A, Gersh BJ. Cell therapy for cardiac repair-lessons from clinical trials. Nat Rev Cardiol. (2014) 11:23246. doi: 10.1038/nrcardio.2014.9

33. Perin EC, Sanz-Ruiz R, Sánchez PL, Lasso J, Pérez-Cano R, AlonsoFarto JC, et al. Adipose-derived regenerative cells in patients with ischemic cardiomyopathy: The PRECISE Trial. Am Heart J. (2014) 168:8895.e82. doi: 10.1016/j.ahj.2014.03.022

34. Bartunek J, Behfar A, Dolatabadi D, Vanderheyden M, Ostojic M, Dens J, et al. Cardiopoietic stem cell therapy in heart failure: the C-CURE (Cardiopoietic stem Cell therapy in heart failURE) multicenter randomized trial with lineage-specified biologics. J Am Coll Cardiol. (2013) 61:232938. doi: 10.1016/j.jacc.2013.02.071

35. Qayyum AA, Haack-Sørensen M, Mathiasen AB, Jørgensen E, Ekblond A, Kastrup J. Adipose-derived mesenchymal stromal cells for chronic myocardial ischemia (MyStromalCell Trial): study design. Regen Med. (2012) 7:421-8. doi: 10.2217/rme.12.17

36. Karp JM, Teo GSL. Mesenchymal stem cell homing: the devil is in the details. Cell Stem Cell. (2009) 4:206-16. doi: 10.1016/j.stem.2009.02.001

37. Li L, Chen X, Wang WE, Zeng C. How to improve the survival of transplanted mesenchymal stem cell in ischemic heart? Stem Cells Int. (2016) 2016:9682757. doi: 10.1155/2016/9682757

38. Zippel N, Schulze M, Tobiasch E. Biomaterials and mesenchymal stem cells for regenerative medicine. Recent Pat Biotechnol. (2010) 4:122. doi: 10.2174/187220810790069497

39. Cassani M, Fernandes S, Vrbsky J, Ergir E, Cavalieri F, Forte G. Combining nanomaterials and developmental pathways to design new treatments for cardiac regeneration: the pulsing heart of advanced therapies. Front Bioeng Biotechnol. (2020) 8:323. doi: 10.3389/fbioe.2020.00323

40. Zammaretti P, Jaconi M. Cardiac tissue engineering: regeneration of the wounded heart. Curr Opin Biotechnol. (2004) 15:4304. doi: 10.1016/j.copbio.2004.08.007

41. Suuronen EJ, Ruel M. Biomaterials for Cardiac Regeneration. Cham: Springer (2015). doi: 10.1007/978-3-319-10972-5

42. Cui Z, Yang B, Li R-K. Application of biomaterials in cardiac repair and regeneration. Engineering. (2016) 2:141-8. doi: 10.1016/J.ENG.2016.01.028

43. Miyagi Y, Chiu LL, Cimini M, Weisel RD, Radisic M, Li K, et al. Biodegradable collagen patch with covalently immobilized VEGF for myocardial repair. Biomaterials. (2011) 32:128090. doi: 10.1016/j.biomaterials.2010.10.007

44. Cheng K, Malliaras K, Shen D, Tseliou E, Ionta V, Smith J, et al. Intramyocardial injection of platelet gel promotes endogenous repair and augments cardiac function in rats with myocardial infarction. J Am Coll Cardiol. (2012) 59:256-64. doi: 10.1016/j.jacc.2011.10.858

45. Lutolf M, Hubbell J. Synthetic biomaterials as instructive extracellular microenvironments for morphogenesis in tissue engineering. Nat Biotechnol. (2005) 23:47-55. doi: 10.1038/nbt1055

46. Prestwich GD. Hyaluronic acid-based clinical biomaterials derived for cell and molecule delivery in regenerative medicine. J Controlled Release. (2011) 155:193-9. doi: 10.1016/j.jconrel.2011.04.007

47. Seliktar D. Designing cell-compatible hydrogels for biomedical applications. Science. (2012) 336:1124-8. doi: 10.1126/science.1214804
48. Davis ME, Hsieh PC, Grodzinsky AJ, Lee RT. Custom design of the cardiac microenvironment with biomaterials. Circ Res. (2005) 97:815. doi: 10.1161/01.RES.0000173376.39447.01

49. Segers VF, Lee RT. Biomaterials to enhance stem cell function in the heart. Circ Res. (2011) 109:910-22. doi: 10.1161/CIRCRESAHA.111.249052

50. Ungerleider JL, Christman KL. Concise review: injectable biomaterials for the treatment of myocardial infarction and peripheral artery disease: translational challenges and progress. Stem Cells Transl Med. (2014) 3:10909. doi: 10.5966/sctm.2014-0049

51. Shen D, Wang X, Zhang L, Zhao X, Li J, Cheng K, et al. The amelioration of cardiac dysfunction after myocardial infarction by the injection of keratin biomaterials derived from human hair. Biomaterials. (2011) 32:92909. doi: 10.1016/j.biomaterials.2011.08.057

52. Ruvinov E, Cohen S. Alginate biomaterial for the treatment of myocardial infarction: progress, translational strategies, and clinical outlook: from ocean algae to patient bedside. Adv Drug Delivery Rev. (2016) 96:5476. doi: 10.1016/j.addr.2015.04.021

53. Levit RD, Landázuri N, Phelps EA, Brown ME, García AJ, Davis ME, et al. Cellular encapsulation enhances cardiac repair. J Am Heart Assoc. (2013) 2:e000367. doi: 10.1161/JAHA.113.000367

54. Roche ET, Hastings CL, Lewin SA, Shvartsman DE, Brudno Y, Vasilyev $\mathrm{NV}$, et al. Comparison of biomaterial delivery vehicles for improving acute retention of stem cells in the infarcted heart. Biomaterials. (2014) 35:68508. doi: 10.1016/j.biomaterials.2014.04.114

55. Dellatore SM, Garcia AS, Miller WM. Mimicking stem cell niches to increase stem cell expansion. Curr Opin Biotechnol. (2008) 19:53440. doi: 10.1016/j.copbio.2008.07.010

56. Tong Z, Solanki A, Hamilos A, Levy O, Wen K, Yin X, et al. Application of biomaterials to advance induced pluripotent stem cell research and therapy. EMBO J. (2015) 34:987-1008. doi: 10.15252/embj.201490756

57. Liu $H$, Webster TJ. Nanomedicine for implants: a review of studies and necessary experimental tools. Biomaterials. (2007) 28:354-69. doi: 10.1016/j.biomaterials.2006.08.049

58. Jiang W, Liu H. Nanocomposites for bone repair and osteointegration with soft tissues. In: Liu $\mathrm{H}$, editor. Nanocomposites for Musculoskeletal Tissue Regeneration. Elsevier (2016). p. 241-57. doi: 10.1016/B978-1-78242-452-9.00011-X

59. Jiang W, Rutherford D, Vuong T, Liu H. Nanomaterials for treating cardiovascular diseases: a review. Bioactive Mater. (2017) 2:185-98. doi: 10.1016/j.bioactmat.2017.11.002

60. Park J, Bauer S, Von Der Mark K, Schmuki P. Nanosize and vitality: TiO2 nanotube diameter directs cell fate. Nano Lett. (2007) 7:168691. doi: 10.1021/nl070678d

61. Oh S, Brammer KS, Li YJ, Teng D, Engler AJ, Chien S, et al. Stem cell fate dictated solely by altered nanotube dimension. Proc Natl Acad Sci USA. (2009) 106:2130-5. doi: 10.1073/pnas.0813200106

62. Pan H-A, Hung Y-C, Sui Y-P. Topographic control of the growth and function of cardiomyoblast $\mathrm{H} 9 \mathrm{c} 2$ cells using nanodot arrays. Biomaterials. (2012) 33:20-8. doi: 10.1016/j.biomaterials.2011.09.054

63. Jiao $\mathrm{Q}, \mathrm{Li} \mathrm{L}, \mathrm{Mu} \mathrm{Q}$, Zhang $\mathrm{Q}$. Immunomodulation of nanoparticles in nanomedicine applications. Biomed Res Int. (2014) 2014:426028. doi: 10.1155/2014/426028

64. Dobrovolskaia MA, Mcneil SE. Immunological properties of engineered nanomaterials. Nat Nanotechnol. (2007) 2:469-78. doi: 10.1038/nnano.2007.223

65. Pagliari F, Mandoli C, Forte G, Magnani E, Pagliari S, Nardone G, et al. Cerium oxide nanoparticles protect cardiac progenitor cells from oxidative stress. ACS Nano. (2012) 6:3767-75. doi: 10.1021/nn2048069

66. Falugi C, Aluigi M, Chiantore M, Privitera D, Ramoino P, Gatti M, et al. Toxicity of metal oxide nanoparticles in immune cells of the sea urchin. Marine Environ Res. (2012) 76:114-21. doi: 10.1016/j.marenvres.2011.10.003

67. Mukherjee S, Reddy Venugopal J, Ravichandran R, Ramakrishna S, Raghunath M. Evaluation of the biocompatibility of PLACL/collagen nanostructured matrices with cardiomyocytes as a model for the regeneration of infarcted myocardium. Adv Funct Mater. (2011) 21:2291-300. doi: 10.1002/adfm.201002434

68. Chang M-Y, Yang Y-J, Chang C-H, Tang ACL, Liao W-Y, Cheng F$\mathrm{Y}$, et al. Functionalized nanoparticles provide early cardioprotection after acute myocardial infarction. J Controlled Release. (2013) 170:28794. doi: 10.1016/j.jconrel.2013.04.022 
69. Martins AM, Eng G, Caridade SG, Mano JF, Reis RL, Vunjak-Novakovic G. Electrically conductive chitosan/carbon scaffolds for cardiac tissue engineering. Biomacromolecules. (2014) 15:635-43. doi: 10.1021/bm401679q

70. Zhou J, Chen J, Sun H, Qiu X, Mou Y, Liu Z, et al. Engineering the heart: evaluation of conductive nanomaterials for improving implant integration and cardiac function. Sci Rep. (2014) 4:1-11. doi: 10.1038/srep03733

71. Anker SD, Coats AJ, Cristian G, Dragomir D, Pusineri E, Piredda M, et al. A prospective comparison of alginate-hydrogel with standard medical therapy to determine impact on functional capacity and clinical outcomes in patients with advanced heart failure (AUGMENT-HF trial). Eur Heart J. (2015) 36:2297-309. doi: 10.1093/eurheartj/ehv259

72. Mann DL, Lee RJ, Coats AJ, Neagoe G, Dragomir D, Pusineri E, et al. One-year follow-up results from AUGMENT-HF: a multicentre randomized controlled clinical trial of the efficacy of left ventricular augmentation with Algisyl in the treatment of heart failure. Eur J Heart Failure. (2016) 18:31425. doi: 10.1002/ejhf.449

73. Al Meslmani BM, Mahmoud GF, Bakowsky U. Development of expanded polytetrafluoroethylene cardiovascular graft platform based on immobilization of poly lactic-co-glycolic acid nanoparticles using a wet chemical modification technique. Int J Pharmaceut. (2017) 529:238-44. doi: 10.1016/j.ijpharm.2017.06.091

74. Ahadian S, Huyer LD, Estili M, Yee B, Smith N, Xu Z, et al. Moldable elastomeric polyester-carbon nanotube scaffolds for cardiac tissue engineering. Acta Biomaterialia. (2017) 52:81-91. doi: 10.1016/j.actbio.2016.12.009

75. Liu N, Chen J, Zhuang J, Zhu P. Fabrication of engineered nanoparticles on biological macromolecular (PEGylated chitosan) composite for bio-active hydrogel system in cardiac repair applications. Int J Biol Macromol. (2018) 117:553-8. doi: 10.1016/j.ijbiomac.2018.04.196

76. Dong $\mathrm{Y}$, Hong $\mathrm{M}$, Dai $\mathrm{R}$, Wu H, Zhu P. Engineered bioactive nanoparticles incorporated biofunctionalized ECM/silk proteins based cardiac patches combined with MSCs for the repair of myocardial infarction: in vitro and in vivo evaluations. Sci Tot Environ. (2020) 707:135976. doi: 10.1016/j.scitotenv.2019.135976

77. Cristallini C, Vitale E, Giachino C, Rastaldo R. Nanoengineering in cardiac regeneration: looking back and going forward. Nanomaterials. (2020) 10:1587. doi: 10.3390/nano10081587

78. Stevenson WG, John RM. Ventricular arrhythmias in patients with implanted defibrillators. Circulation. (2011) 124:e4114. doi: 10.1161/CIRCULATIONAHA.111.064816

79. Witte KK, Pipes RR, Nanthakumar K, Parker JD. Biventricular pacemaker upgrade in previously paced heart failure patientsimprovements in ventricular dyssynchrony. J Cardiac Failure. (2006) 12:199-204. doi: 10.1016/j.cardfail.2005. 12.003

80. Radisic M, Park H, Shing H, Consi T, Schoen FJ, Langer R, et al. Functional assembly of engineered myocardium by electrical stimulation of cardiac myocytes cultured on scaffolds. Proc Natl Acad Sci USA. (2004) 101:1812934. doi: 10.1073/pnas.0407817101

81. Balint R, Cassidy NJ, Cartmell SH. Conductive polymers: Towards a smart biomaterial for tissue engineering. Acta Biomaterialia. (2014) 10:234153. doi: 10.1016/j.actbio.2014.02.015

82. Nakashima T, Ohkusa T, Okamoto Y, Yoshida M, Lee J-K, et al. Rapid electrical stimulation causes alterations in cardiac intercellular junction proteins of cardiomyocytes. Am J Physiol Heart Circ Physiol. (2014) 306:H1324-33. doi: 10.1152/ajpheart.00653.2013

83. Lee WC, Lim CHY, Shi H, Tang LA, Wang Y, Lim CT, et al. Origin of enhanced stem cell growth and differentiation on graphene and graphene oxide. ACS Nano. (2011) 5:7334-41. doi: 10.1021/nn20 $2190 \mathrm{c}$

84. Shi X, Chang H, Chen S, Lai C, Khademhosseini A, Wu H. Regulating cellular behavior on few-layer reduced graphene oxide films with well-controlled reduction states. Adv Funct Mater. (2012) 22:751-9. doi: 10.1002/adfm.2011 02305

85. Orecchioni M, Ménard-Moyon C, Delogu LG, Bianco A. Graphene and the immune system: challenges and potentiality. $A d v$ Drug Delivery Rev. (2016) 105:163-75. doi: 10.1016/j.addr.2016. 05.014
86. Ma Y, Mouton AJ, Lindsey ML. Cardiac macrophage biology in the steadystate heart, the aging heart, and following myocardial infarction. Transl Res. (2018) 191:15-28. doi: 10.1016/j.trsl.2017.10.001

87. Franz S, Rammelt S, Scharnweber D, Simon JC. Immune responses to implants-a review of the implications for the design of immunomodulatory biomaterials. Biomaterials. (2011) 32:6692-709. doi: 10.1016/j.biomaterials.2011.05.078

88. Mukherjee SP, Bottini M, Fadeel B. Graphene and the immune system: a romance of many dimensions. Front Immunol. (2017) 8:673. doi: 10.3389/fimmu.2017.00673

89. Malanagahalli S, Murera D, Martín C, Lin H, Wadier N, Dumortier H, et al. Few layer graphene does not affect cellular homeostasis of mouse macrophages. Nanomaterials. (2020) 10:228. doi: 10.3390/nano10020228

90. Sattler S, Fairchild P, Watt FM, Rosenthal N, Harding SE. The adaptive immune response to cardiac injury-the true roadblock to effective regenerative therapies? NPJ Regen Med. (2017) 2:1-5. doi: 10.1038/s41536-017-0022-3

91. Wagner MJ, Khan M, Mohsin S. Healing the broken heart, the immunomodulatory effects of stem cell therapy. Front Immunol. (2020) 11:639. doi: 10.3389/fimmu.2020.00639

92. Tomić S, Janjetović K, Mihajlović D, Milenković M, Kravić-Stevović T, Marković Z, et al. Graphene quantum dots suppress proinflammatory T cell responses via autophagy-dependent induction of tolerogenic dendritic cells. Biomaterials. (2017) 146:13-28. doi: 10.1016/j.biomaterials.2017.08.040

93. Wang J, Cui C, Nan H, Yu Y, Xiao Y, Poon E, et al. Graphene sheet-induced global maturation of cardiomyocytes derived from human induced pluripotent stem cells. ACS Appl Mater interfaces. (2017) 9:25929940. doi: 10.1021/acsami.7b08777

94. Park J, Kim B, Han J, Oh J, Park S, Ryu S, et al. Graphene oxide flakes as a cellular adhesive: prevention of reactive oxygen species mediated death of implanted cells for cardiac repair. ACS Nano. (2015) 9:498799. doi: 10.1021/nn507149w

95. Wang B, Su X, Liang J, Yang L, Hu Q, Shan X, et al. Synthesis of polymerfunctionalized nanoscale graphene oxide with different surface charge and its cellular uptake, biosafety and immune responses in Raw264. 7 macrophages. Mater Sci Eng C. (2018) 90:514-22. doi: 10.1016/j.msec.2018.04.096

96. Paul A, Hasan A, Kindi HA, Gaharwar AK, Rao VT, Nikkhah M, et al. Injectable graphene oxide/hydrogel-based angiogenic gene delivery system for vasculogenesis and cardiac repair. ACS Nano. (2014) 8:805062. doi: $10.1021 / \mathrm{nn} 5020787$

97. Bao R, Tan B, Liang S, Zhang N, Wang W, Liu W. A $\pi-\pi$ conjugationcontaining soft and conductive injectable polymer hydrogel highly efficiently rebuilds cardiac function after myocardial infarction. Biomaterials. (2017) 122:63-71. doi: 10.1016/j.biomaterials.2017.01.012

98. Saravanan S, Sareen N, Abu-El-Rub E, Ashour H, Sequiera GL, Ammar HI, et al. Graphene oxide-gold nanosheets containing chitosan scaffold improves ventricular contractility and function after implantation into infarcted heart. Sci Rep. (2018) 8:1-13. doi: 10.1038/s41598-018-33144-0

99. Choe G, Kim S-W, Park J, Park J, Kim S, et al. Anti-oxidant activity reinforced reduced graphene oxide/alginate microgels: mesenchymal stem cell encapsulation and regeneration of infarcted hearts. Biomaterials. (2019) 225:119513. doi: 10.1016/j.biomaterials.2019.119513

100. Nazari H, Azadi S, Hatamie S, Zomorrod MS, Ashtari K, Soleimani M, et al. Fabrication of graphene-silver/polyurethane nanofibrous scaffolds for cardiac tissue engineering. Polymers Adv Technol. (2019) 30:20862099. doi: 10.1002/pat.4641

101. Nazari H, Heirani-Tabasi A, Alavijeh MS, Jeshvaghani ZS, Esmaeili E, Hosseinzadeh S, et al. Nanofibrous composites reinforced by MoS2 Nanosheets as a conductive scaffold for cardiac tissue engineering. ChemistrySelect. (2019) 4:11557-63. doi: 10.1002/slct.201901357

102. Basara G, Saeidi-Javash M, Ren X, Bahcecioglu G, Wyatt BC, Anasori $B$, et al. Electrically conductive 3D printed Ti3C2Tx MXene-PEG composite constructs for cardiac tissue engineering. Acta Biomaterialia. (2020). doi: 10.1016/j.actbio.2020.12.033. [Epub ahead of print].

103. Ye G, Wen Z, Wen F, Song X, Wang L, Li C, et al. Musselinspired conductive Ti2C-cryogel promotes functional maturation of cardiomyocytes and enhances repair of myocardial infarction. Theranostics. (2020) 10:2047. doi: 10.7150/thno.38876 
104. Rafieerad A, Yan W, Sequiera GL, Sareen N, Abu-El-Rub E, Moudgil M, et al. Quantum dots: application of Ti3C2 MXene quantum dots for immunomodulation and regenerative medicine. Adv Healthcare Mater. (2019) 8:1970067. doi: 10.1002/adhm.201970067

105. Rafieerad A, Yan W, Alagarsamy KN, Srivastava A, Sareen N, Arora RC, et al. Fabrication of smart tantalum carbide MXene quantum dots with intrinsic immunomodulatory properties for treatment of allograft vasculopathy. $A d v$ Funct Mater. (2021) 2021:2106786. doi: 10.1002/adfm.202106786

106. Alagarsamy KN, Mathan S, Yan W, Rafieerad A, Sekaran S, Manego $\mathrm{H}$, et al. Carbon nanomaterials for cardiovascular theranostics: promises and challenges. Bioactive Mater. (2021) 6:2261-80. doi: 10.1016/j.bioactmat.2020.12.030

107. Gazzi A, Fusco L, Orecchioni M, Ferrari S, Franzoni G, Yan JS, et al. Graphene, other carbon nanomaterials and the immune system: toward nanoimmunity-by-design. J Phys Mater. (2020) 3:034009. doi: 10.1088/2515-7639/ab9317

108. Okita K, Ichisaka T, Yamanaka S. Generation of germline-competent induced pluripotent stem cells. Nature. (2007) 448:313-7. doi: 10.1038/nature05934

109. Takahashi K, Tanabe K, Ohnuki M, Narita M, Ichisaka T, Tomoda K, et al. Induction of pluripotent stem cells from adult human fibroblasts by defined factors. Cell. (2007) 131:861-72. doi: 10.1016/j.cell.2007.11.019

110. Cicha I, Singh R, Garlichs CD, Alexiou C. Nano-biomaterials for cardiovascular applications: clinical perspective. J Controlled Release. (2016) 229:23-36. doi: 10.1016/j.jconrel.2016.03.015

111. Fadeel B, Bussy C, Merino S, Vázquez E, Flahaut E, Mouchet F, et al. Safety assessment of graphene-based materials: focus on human health and the environment. ACS Nano. (2018) 12:10582-620. doi: 10.1021/acsnano.8b04758

112. Shin SR, Aghaei-Ghareh-Bolagh B, Gao X, Nikkhah M, Jung SM, Dolatshahi-Pirouz A, et al. Layer-by-layer assembly of $3 \mathrm{D}$ tissue constructs with functionalized graphene. Adv Funct Mater. (2014) 24:6136-44. doi: 10.1002/adfm.201401300

113. Wang L, Jiang J, Hua W, Darabi A, Song X, Song C, et al. Mussel-inspired conductive cryogel as cardiac tissue patch to repair myocardial infarction by migration of conductive nanoparticles. Adv Funct Mater. (2016) 26:4293305. doi: 10.1002/adfm.201505372

114. Zhou J, Yang X, Liu W, Wang C, Shen Y, Zhang F, et al. Injectable $\mathrm{OPF} /$ graphene oxide hydrogels provide mechanical support and enhance cell electrical signaling after implantation into myocardial infarct. Theranostics. (2018) 8:3317. doi: 10.7150/thno.25504

115. Jing X, Mi H-Y, Napiwocki BN, Peng X-F. Mussel-inspired electroactive chitosan/graphene oxide composite hydrogel with rapid self-healing and recovery behavior for tissue engineering. Carbon. (2017) 125:55770. doi: 10.1016/j.carbon.2017.09.071

116. Jiang L, Chen D, Wang Z, Zhang Z, Xia Y, Xue H, et al. Preparation of an electrically conductive graphene oxide/chitosan scaffold for cardiac tissue engineering. Appl Biochem Biotechnol. (2019) 188:952-64. doi: 10.1007/s12010-019-02967-6

117. Ghasemi A, Imani R, Yousefzadeh M, Bonakdar S, Solouk A, Fakhrzadeh H. Studying the potential application of electrospun polyethylene terephthalate/graphene oxide nanofibers as electroconductive cardiac patch. Macromol Mater Eng. (2019) 304:1900187. doi: 10.1002/mame.201900187

118. Zhao L. A novel graphene oxide polymer gel platform for cardiac tissue engineering application. 3 Biotech. (2019) 9:1-11. doi: 10.1007/s13205-019-1912-4

119. Zhang F, Zhang N, Meng H-X, Liu H-X, Li Y-Q, Liu C-M, et al. Easy applied gelatin-based hydrogel system for long-term functional cardiomyocyte culture and myocardium formation. ACS Biomater Sci Eng. (2019) 5:302231. doi: 10.1021 /acsbiomaterials.9b00515

120. Park J, Kim YS, Ryu S, Kang WS, Park S, Han J, et al. Graphene potentiates the myocardial repair efficacy of mesenchymal stem cells by stimulating the expression of angiogenic growth factors and gap junction protein. Adv Funct Mater. (2015) 25:2590-600. doi: 10.1002/adfm.201500365

121. Shin SR, Zihlmann C, Akbari M, Assawes P, Cheung L, Zhang K, et al. Reduced graphene oxide-gelMA hybrid hydrogels as scaffolds for cardiac tissue engineering. Small. (2016) 12:3677-89. doi: 10.1002/smll.201600178

122. Norahan MH, Pourmokhtari M, Saeb MR, Bakhshi B, Zomorrod MS, Baheiraei N. Electroactive cardiac patch containing reduced graphene oxide with potential antibacterial properties. Mater Sci Eng C. (2019) 104:109921. doi: 10.1016/j.msec.2019.109921

123. Stone H, Lin S, Mequanint K. Preparation and characterization of electrospun rGO-poly (ester amide) conductive scaffolds. Mater Sci Eng C. (2019) 98:324-32. doi: 10.1016/j.msec.2018.12.122

124. Zargar SM, Mehdikhani M, Rafienia M. Reduced graphene oxidereinforced gellan gum thermoresponsive hydrogels as a myocardial tissue engineering scaffold. J Bioactive Compat Polymers. (2019) 34:33145. doi: $10.1177 / 0883911519876080$

125. Hu J, Sun X, Ma H, Xie C, Chen YE, Ma PX. Porous nanofibrous PLLA scaffolds for vascular tissue engineering. Biomaterials. (2010) 31:79717. doi: 10.1016/j.biomaterials.2010.07.028

126. Xie C, Hu J, Ma H, Zhang J, Chang L-J, Chen E, et al. Threedimensional growth of iPS cell-derived smooth muscle cells on nanofibrous scaffolds. Biomaterials. (2011) 32:4369-75. doi: 10.1016/j.biomaterials.2011. 02.049

127. Wang $\mathrm{Y}$, $\mathrm{Hu}$ J, Jiao J, Liu Z, Zhou Z, Zhao $\mathrm{C}$, et al. Engineering vascular tissue with functional smooth muscle cells derived from human iPS cells and nanofibrous scaffolds. Biomaterials. (2014) 35:8960-9. doi: 10.1016/j.biomaterials.2014. 07.011

128. Ho CMB, Mishra A, Lin PTP, Ng SH, Yeong WY, Kim YJ, et al. 3D printed polycaprolactone carbon nanotube composite scaffolds for cardiac tissue engineering. Macromol Biosci. (2017) 17:1600250. doi: 10.1002/mabi.2016 00250

129. Maiullari F, Costantini M, Milan M, Pace V, Chirivì M, Maiullari $\mathrm{S}$, et al. A multi-cellular 3D bioprinting approach for vascularized heart tissue engineering based on HUVECs and iPSC-derived cardiomyocytes. Sci Rep. (2018) 8:1-15. doi: 10.1038/s41598-018-3 1848-x

130. Yang B, Yin J, Chen Y, Pan S, Yao H, Gao Y, et al. 2D-blackphosphorus-reinforced 3D-printed scaffolds: a stepwise countermeasure for osteosarcoma. Adv Mater. (2018) 30:1705611. doi: 10.1002/adma.2017 05611

131. Mehrotra S, Singh RD, Bandyopadhyay A, Janani G, Dey S, Mandal BB. Engineering microsphere-loaded non-mulberry silk-based 3D bioprinted vascularized cardiac patches with oxygen-releasing and immunomodulatory potential. ACS Appl Mater Interfaces. (2021) 13:50744-59. doi: 10.1021/acsami.1c14118

132. Huang NF, Serpooshan V, Morris VB, Sayed N, Pardon G, Abilez OJ, et al. Big bottlenecks in cardiovascular tissue engineering. Commun Biol. (2018) 1:1-4. doi: 10.1038/s42003-018-02 $02-8$

133. Liu X, Miller AL, Park S, George MN, Waletzki BE, Xu $\mathrm{H}$, et al. Two-dimensional black phosphorus and graphene oxide nanosheets synergistically enhance cell proliferation and osteogenesis on 3D printed scaffolds. ACS Appl Mater Interfaces. (2019) 11:23558-72. doi: 10.1021/acsami.9b 04121

Conflict of Interest: The authors declare that the research was conducted in the absence of any commercial or financial relationships that could be construed as a potential conflict of interest.

Publisher's Note: All claims expressed in this article are solely those of the authors and do not necessarily represent those of their affiliated organizations, or those of the publisher, the editors and the reviewers. Any product that may be evaluated in this article, or claim that may be made by its manufacturer, is not guaranteed or endorsed by the publisher.

Copyright (c) 2022 Gokce, Gurcan, Delogu and Yilmazer. This is an open-access article distributed under the terms of the Creative Commons Attribution License (CC $B Y)$. The use, distribution or reproduction in other forums is permitted, provided the original author(s) and the copyright owner(s) are credited and that the original publication in this journal is cited, in accordance with accepted academic practice. No use, distribution or reproduction is permitted which does not comply with these terms. 